\title{
MENINGKATKAN PENDAPATAN MASYARAKAT MELALUI PENGELOLAAN SAMPAH
}

\author{
Dewi Saptantinah $\mathbf{P}^{1)}$ \\ Fadjar Harimurti ${ }^{2)}$ \\ Merkuria Karyantina ${ }^{3)}$ \\ Universitas Slamet Riyadi Surakarta \\ dewi.astutie@gmail.com
}

\begin{abstract}
ABSTRAKSI
Kegiatan Usaha Kecil Menengah pada saat ini memiliki peran strategis dalam perekonomian Indonesia, terutama dalam meningkatkan pendapatan masyarakat. Hal ini terjadi pada usaha home industry bank sampah Handono Mulyo dan Bank sampah Dewaruci yang mengelola sampah menjadi produk yang dapat dimanfaatkan dan memiliki nilai jual, yaitu membuat pupuk kompos padat maupun cair dari sampah organik dan mmbuat berbagai kerajinan asesoris dari sampah anorganik. Hasil kerajinan tersebut dijual dan hasilnya dikelola oleh bank sampah untuk kemudian dapat meningkatkan pendapatan masyarakat. Kegiatan pengabdian ini berusaha untuk memfasilitasi berbagai masalah yang ada pada mitra dan menawarkan berbagai solusi agar kegiatan mitra dapat berkembang serta dapat lebih produktif. Disamping itu dengan adanya pengelolaan sampah maka mitra memiliki keuntungan selain untuk meningkatkan pendapatan masyarakat juga dapat mengelola sampah untuk dapat mengurangi permasalahan sampah di masyarakat.

Kata Kunci: Sampah organik, sampah anorganik, pendapatan
\end{abstract}

\section{ABSTRACTION}

Small and Medium Enterprises currently have a strategic role in the Indonesian economy, especially in increasing community income. This happened to the waste bank home industry business Handono Mulyo and Dewaruci garbage bank that manages waste into products that can be used and have a selling value, namely making solid or liquid compost from organic waste and making various accessories from inorganic waste. The results of the handicrafts are sold and the results are managed by the waste bank to then increase the people's income. This service activity seeks to facilitate various problems that exist in partners and offer various solutions so that partner activities can develop and can be more productive. Besides that with the existence of waste management, the partners have the advantage in addition to increasing the income of the community can also manage waste to reduce waste problems in the community.

Key words : Organic waste, anorganic waste, income

\section{PENDAHULUAN}

Dewasa ini pertumbuhan Usaha Kecil Menengah (UKM) mengalami pertumbuhan pesat, bahkan pertumbuhan perekonomian di Indonesia sebagian besar adalah karena peran dari usaha kecil tersebut. Di daerah perkotaan maupun di pinggiran kota banyak yang berawal dari usaha home industry yang akhirnya mengalami kemajuan usahanya dan akhirnya tumbuh menjadi Usaha Kecil Menengah Menurut Prihatin Lumbanraja dkk (2017) Usaha Kecil Menengah memiliki arti strategis bagi pembangunan dan juga sebagai sarana memeratakan hasil pembangunan. Usaha Kecil Menengah atau UKM itu sendiri didefinisikan sebagai usaha kecil yang memiliki kekayaan bersih paling banyak Rp. 200.000.000, 00 dan nilai tersebut tidak termasuk tanah dan bangunan tempat usaha. Sehingga dari definisi tersebut maka kriteria UKM adalah memiliki kekayaan bersih paling banyak Rp. 200.000.000 dan hasil penjualan tahunan maksimal Rp. 1.000.000.000, milik Warga Negara Indonesia, bentuk usaha perorangan 
(wikipedia.org). Bertumbuhnya home industry dan usaha kecil menengah sangat membantu dalam meningkatkan pendapatan masyarakat, jenis home industry yang mengalami pertumbuhan dan akhirnya menjadi Usaha Kecil Menengah diantaranya dari usaha kerajinan, misalnya membuat berbagai kerajinan asesoris dari barang bekas yang dengan kreatifitasnya akhirnya dapat menghasilkan berbagai kerajinan yang dapat dijual ke masyarakat.

Tak terkecuali juga dari kegiatan pengabdian ini. Miitra dari kegiatan pengabdian ini kesemuanya adalah berawal dari home industry, dimana kegiatannya adalah dengan memanfaatkan barang bekas, yaitu dengan mengelola sampah masyarakat yang sangat mengganggu pemukiman penduduk. Apabila dibiarkan sampah tersebut selain mengganggu pandangan juga menjadi pemicu terjadinya penyakit, karena lingkungan kotor yang dapat mengakibatkan lingkungan yang tercemar. Oleh karena itu berawal dari hal tersebut maka perlu dilakukan pengelolaan sampah dengan mengubah sampah tersebut menjadi produk yang berguna. Mitra pengabdian kami melakukan pengelolaan sampah setidaknya sebagai upaya mengurangi masalah sampah yang menumpuk. Dua mitra dalam pengabdian ini yang satu mitra mengubah sampah organik menjadi pupuk dan satu mitra mengubah sampah anorganik menjadi berbagai kerajinan. Adapun yang menjadi obyek dalam kegiatan pengabdian ini adalah BKM Handono Mulyo di Desa Jaten, yang terfokus kepada kegiatan membuat pupuk kompos, sedangkan obyek yang satunya adalah Bank Sampah Dewaruci yang terletak di Desa Ngijo yang fokusnya adalah membuat kerajinan dari sampah anorganik. Kedua obyek mitra tersebut terletak di Kabupaten Karanganyar Jawa Tengah.

Identifikasi permasalahan yang dihadapi mitra adalah untuk Bank Sampah BKM Handono Mulyo adalah minimnya fasilitas terutama peralatan dalam membuat sampah, sedangkan untuk Bank sampah Dewaruci selain terkendala peralatan untuk membuat kerajinan asesoris juga kurangnya variasi dalam membuat asesoris. Kesamaan masalah yang dihadapi kedua mitra adalah sama-sama mengalami kesulitan dalam memasarkan hasil produksinya.

Untuk itu tim pengabdian kami berusaha untuk menawarkan berbagai solusi untuk membantu memecahkan masalah tersebut. Tujuan dari kegiatan pengabdian ini adalah untuk memfasilitasi beberapa permasalahan yang dihadapi mitra dan menawarkan solusi dari masalah tersebut, sedangkan tujuan dari penulisn artikel ini adalah untuk memberikan gambaran mengenai kegiatan pengabdian yang kami lakukan dari awal sampai dengan menghasilkan suatu produk dari pengelolaan sampah kemudian dijual dan hasilnya dapat meningkatkan pendapatan masyarakat. Menuruti I Nyomaan Wardi bahwa bahwa pengelolaan sampah yang baik memiliki keuntungan ekonomi dan sosial, keuntungan ekonomi dapat meningkatkan pendapatan sedangkan keuntungan sosial adalah diperolehnya nilai estetika lingkungan (I Nyoman Wardi(2011) dalam Siska Maya dkk (2017).

\section{Luaran Kegiatan}

Luaran Kegiatan pengabdian adalah berikut ini:

1. Menghasilkan pupuk kompos dari bahan sampah organik yang sudah dicacah untuk diolah menjadi kompos dan pupuk cair dari hasil proses menggunakan tong komposter

2. Menghasilkan kerajinan berbagai asesoris dari bahan anorganik yang bervariasi dari hasil pelatihan ketrampilan

3. Meningkatnya ketrampilan pengelolaan keuangan serta pencatatan keuangan dan adminstrasi yang lebih lengkap

4. Meningkatnya kegiatan pemasaran, sehingga produk yang dihasilkan tidak menumpuk tetapi laku terjual dan menambah pendapatan masyarakat

\section{METODE PELAKSANAAN}

Berdasar pada permasalahan yang diuraikan di atas maka kegiatan pengabdian ini dilaksanakan dengan metode seperti berikut ini:

1. Melakukan survey pendahuluan untuk mengetahui permasalahan yang dihadapi mitra

2. Melakukan koordinasi dengan kedua mitra mengenai kegiatan pengabdian yang akan dilakukan serta menjelaskan tujuan dari kegiatan pengabdian 
3. Memberikan solusi dari permasalahan yang ada

4. Memfasilitasi mitra, yaitu dengan pengadaan mesin pencacah sampah untuk selanjutnya dapat dproses untuk dibuat pupuk

5. Memfasilitasi dengan pemberian bantuan peralatan untuk membuat berbagai kerajinan asesoris dan sampah anorganik

6. Melakukan pendampingan berupa sosialiasi dan pemberian pelatihan berbagai hal, yaitu pembuatan pupuk, pembuatan berbagai kerajinan asesoris dari sampah anorganik dan pelatihan cara pengelolaan keuangan dari hasil penjualan kerajinan dan hasil pupuk tersebut.

\section{HASIL DAN PEMBAHASAN}

Kegiatan pengabdian masyarakat ini sudah dimulai sejak awal tahun 2018, karena pada tahun sebelumnya sudah kami lakukan survey pada mitra, sehingga pada saat pelaksanaan kegiatan tim kami sudah memperoleh beberapa solusi yang perlu ditawarkan kepada mitra. Kegiatan pengabdian kami dilaksanakan di Desa Jaten dan Desa Ngijo Kabupaten Karanganyar.

Kedua mitra tersebut memiliki fokus kegiatan yang berbeda. Mitra satu yaitu Bank Sampah BKM Handono Mulyo dan mitra kedua Bank Sampah Dewaruci. Kedua mitra tersebut sebenarnya cukup prospektif, karena keduanya terletak di daerah pemukiman yang padat penduduk. BKM Handono Mulyo terletak di lingkungan perumahan yang padat, dalam hal ini menghadapi masalah sampah yang menumpuk yang menutup akses dari perumahan satu ke perumahan lainnya, dengan demikian perlu penataan agar akses dan lingkungan terlihat asri. Salah satu solusi yang kami tawarkan adalah mengolah sampah organik menjadi pupuk. Karena kendala peralatan yang belum dimiliki, maka tim kami memfasilitasi mesin pencacah sampah organik. Kemudian setelah dicacah dapat diproses untuk dibuat pupuk kompos, dan tim kami juga memfasilitasi tong komposter yang bermanfaat untuk menampung sampah warga sehari-hari dari sampah organik untuk dijadikan pupuk cair.

Adapun untuk mitra kedua adalah Bank Sampah Dewaruci, yang lebih memfokuskan pada penangan sampah anorganik untuk dibuat berbagai kerajinan asesoris, seperti bros dan berbagai asesoris lainnya. Hal ini dikarenakan di bank sampah ini pengelolanya adalah ibu-ibu rumah tangga, sehingga ketrampilan adalah menjadi bagian dari keseharian ibu-ibu pengurus bank sampah ini. Permasalahan yang dihadapi adalah kurangnya kreatifitas dalam membuat berbagai asesoris dan terbatasnya perlatan dalam membuat asesoris, dan juga masih belum memiliki solusi cara memasarkan produk mereka. Dengan demikian tim kami menawarkan solusi untuk memberikan pelatihan cara membuat berbagai variasi kerajinan dari sampah anorganik, dan juga memfasilitasi berbagai peralatan dalam membuat asesoris dan agar produk lebih mudah dilihat oleh orang maka kami memberikan rak etalase untuk memajang hasil produksi kerajinan.

Kegiatan pada dua mitra tersebut kami laksanakan sekitar bulan April sampai dengan Juni 2018. Dan hasil yang kami harapkan adalah dari produk yang dihasilkan tersebut dapat dijual dengan demikian hasil penjualan dapat menambah pendapatan masyarakat. Untuk itu dengan adanya bank sampah diharapkan dapat mengelola hasil pendapatan dari penjualan produk tersebut dan akhirnya juga akan meningkatkan pendapatan masyarakat.

Sebagai antisipasi ke depannya dalam mengelola pendapatan dan mengelola keuangan,maka tim juga melaksanakan pelatihan cara pengelolaan keuangan yang baik dan memberikan contoh cara pencatatan yang benar.

Dalam hal pemasaran hasil produksi, tim kami juga memberikan solusi untuk membantu cara memasarkan produk agar produk lebih dikenal masyarakat, yaitu dengan cara membuatkan kemasan pupuk agar lebih menarik dan membantu membuatkan web untuk sarana memasarkan hasil produksi mereka.

\section{KESIMPULAN}


Kegiatan pengabdian kami lakukan pada dua mitra bank sampah, yang keduanya terletak di Kabupaten Karanganyar. Fokus kedua bank sampah memiliki perbedaan, yaitu untuk bank sampah Handono Mulyo yang terlatak di Desa jaten dalam usaha mengurangi sampah dengan cara memanfaatkan sampah organik diolah menjadi pupuk kompos padat maupun cair, untuk itu tim pengabdian memfasilitasi mesin pencacah sampah yang hasil dari pencacahan tadi diolah menjadi pupuk. Sedangkan bank sampah Dewaruci lebih fokus pada memanfaatkan sampah anorganik menjadi berbagai kerajinan asesoris. Untuk itu tim pengabdian kami berusaha untuk memfasilitasi berbagai peralatan yang digunakan untuk mendukung kegiatan mitra, agar dapat menghasilkan produk dan dapat dijual, sehingga hasil penjualan dapat digunakan untuk menambah pendapatan masyarakat. Dengan demikian kegiatan pengabdian ini diharapkan dapat memberikan manfaat kepada mitra.

\section{DAFTAR PUSTAKA}

Ade Octavia dkk. 2015. Pemberdayaan Masyarakat Melalui Optimalisasi Program Bank Sampah Dengan Bantuan Teknis dan Manajemen Usaha pada KSM Aneka Limbah dan KSM Maidanul Ula Kota Jambi. Jurnal Pengabdian Masyarakat, Vol 30 No.3. Hal 40-49.

https://id.wikipedia.org/wiki/Usaha Kecil dan Menengah. Diakses pada tanggal 3 Oktober 2018.

Prihatin Lumbanraja dkk. 2017. Pengembangan Usaha Mikro Kecil dan Menengah (UMKM) Kerajinan Menjahit dan Bordir di Kecamatan Medan Area Kota Medan. Abdimas Talenta 2 (1), 40-47 vol 2. http://jurnal.usu.ac.id/abdimas.

Siska Maya dkk.2017. Pemberdayaan Masyarakat Melalui Pengelolaan Sampah Menjadi Nilai Ekonomis dan Pembentukan Bank Sampah di Kelurahan Tanjung Barat. Proceeding of Community Development, Vol 1. Hal 157-161. 